\title{
GEOLOGICAL MAP OF THE WORLD
}

$\mathrm{T}$ HE Commission for the Geological Map of the World met in Paris during March 31-April 12. This Commission was founded in 1910 at the Stockholm International Congress and has been reorganized twice since the Second World War. At the Mexico International Geological Congress in 1956 two SubCommissions were created : (1) for the Tectonic Map of the World, and (2) for the Metallogenic Map of the World. The Paris meeting. was organized to establish an international basis and co-ordination for an immediate start on these three maps of the World : geological, tectonic and metallogenic, on an agreed universal scale, legend and principles of construction. The Commission's aim is to promote the construction of such maps for the following regions of the Earth : North America, South America, Europe, Africa, U.S.S.R., Asia, Oceania, Arctic and Antarctic. The Commission is planning to publish a Geological Atlas of the World at the scale $1: 10,000,000$ based on maps at the scale of $1: 5,000,000$. The latter scale is suggested for the tectonic and metallogenic maps. Detailed programmes for the realization of these maps were worked out by the Commission and a number of specific recommendations from various countries or groups of countries were accepted. The aim of the metallogenic map is to record the relations between geology, tectonics and the mineral deposits in any given region. It was also suggested that prior to the construction of such maps, mineral maps accompanied by indexes of mineral deposits should be prepared. It is hoped that these maps, at least in manuscript draft form will be ready for display at the International Geological Congress to be held in Copenhagen in 1960.

Sixty-one countries were represented at the Paris meeting by delegates and assisting geologists. The president of the Commission, elected in 1952, is
F. Blondel, who is assisted by his secretariat at 20 , rue Monsieur, Paris 7e, France. The vice-presidents for the selected regions are as follows: North and Central America, W. D. Johnston, jun.; South America, A. R. Lamego; Europe, A. Bentz; Africa, F. Dixey ; U.S.S.R., N. A. Beliaevsky ; Asia, V. P. Sondhi ; Oceania, J. M. Rayner.

A Select Committee under the presidency of $F$. Dixey examined suggestions for the general legend of the Geological Map of the World and drafted a set of recommendations. Similar work was done for the tectonic map by the special sub-commission (president, N. S. Shatsky ; secretary, A. A. Bogdanov), and for the metallogenic map by the special sub. commission (president, W. D. Johnston, jun.; secretary, P. Routhier). Possibilities of preparing a coal map of Europe were also discussed.

Besides the meetings of the Commissions, a number of meetings dealing with various associated problems were held, such as the International Geological Abstracting Service, presided over by H. M. E. Schurmann, the Committee on Stratigraphy, the Mediterranean-Alpine Committee and others.

During the fortnight's working of the Commission, a number of official receptions were held, which allowed a closer contact between the visiting geologists and their French colleagues, and the strenuous work of the Commission was relieved at the weekend by a visit to the cathedral towns and the castles of the Loire region. The meeting of such a number of geologists from so many countries, animated by the same enthusiasm and purpose, testifies to a most healthy situation in the world of international science. The effective and profitable results of the meeting are, in no small measure, due to the most efficient organization of the Commission by its president and secretariat.

\section{MUSEUMS ASSOCIATION CONFERENCE}

$\mathrm{T}$ HE sixty-fourth annual conference of the Museums Association was held in London during July 7-12, and was attended by more than 700 delegates, among whom were some 70 members of De Museumdag from Holland. It was held in Britain to enable the British delegates to return in some measure the hospitality and courtesy extended to them on their visit to Amsterdam in 1956.

The meetings were held in the Beveridge Hall of the University of London and the official welcome was given by the Minister of Education (the Right Hon. Geoffrey Lloyd), who stressed the view of his Ministry that there should be more co-operation between local authorities and private bodies in the maintenance of museums. He welcomed the increasing part that museums were taking in the educational field and said that the Government was well aware of the difficulties of the small museum. Various suggestions had been made and meanwhile his Ministry was watching with interest the development of plans for a regional museum service.

During his presidential address Sir Philip Hendy, director of the National Gallery, dealt with various problems in the museum and art gallery field. First, he mentioned that the tremendous assistance given by the Carnegie United Kingdom Trust in the past is likely to be reduced in the future. He expressed the strong opinion of the Association that it should be replaced by Government assistance of a substantial nature. He then dealt with the recent controversy arising from the enlightened provisions of the Finance Act, 1956, whereby works of art could be accepted in payment of death duties. It was discouraging that a difference had arisen between local and national claims over the Chatsworth treasures. He believed that objects of the highest quality should go to the national collections, as they and they alone could provide the proper context and setting for such material. He also felt that the provisions of the Finance Act could be used for other objects that would be useful in building up the collections of local museums and would otherwise be almost certainly exported from Great Britain.

Dr. A. B. de Vries, president of De Museumdag, also spoke and enumerated some of the qualities necessary in a museum curator. 
A complete session was given to a discussion concerning museums in the Cornmonwealth and Overseas with especial reference to the training of curators. Dr. D. B. Harden, chairman, in opening the discussion, referred to the progress that had already been made with training schemes in South Africa and Canada and expressed the hope that an overseas secretary would be appointed at no distant date to deal with the furtherance of international relationships between the home country, the Dominions and other smaller countries within the Commonwealth. Subsequent speakers included professional museum staff from parts of Africa, Pakistan and Singapore. It was stated by Prof. P. L. Shinnie of the University of Ghana that countries which had recently achieved their independence would not be content with having their museums staffed by English people. On the other hand, Africans with good degrees would scarcely be willing to accept museum posts when there were far more attractive openings in the Civil Service. $\mathrm{He}$ felt that the training of technicians could be dealt with in Africa but that curators should have the benefit of a European tour of representative institutions. Dr. L. S. Russell, secretary of the Museums Association in Canada, stated that an inquiry had, contrary to the accepted idea, shown that the chief difficulty in that country was not geographical separation but diversity of subject-matter.

Another session, under the chairmanship of Dr. W. E. Swinton, was devoted to museum architecture. It was opened by Mr. Sheppard Fidler, city architect of Birmingham, who described in detail the reconstruction of the galleries which had been so severely bombed during the War. Dr. H. L. C. Jaffé, Amsterdam, dealt with the many building schemes which had taken place in Holland and several other speakers contributed to the discussion.
In proposing a resolution which deplored the continual negative attitude of H.M. Government towards granting assistance to local museums and art galleries, and urging that everything should be done to acquaint those in authority and others with the facts, Sir Mortimer Wheeler felt that the Standing Commission was an eminent body but of no service to provincial museums. He stressed the urgent need for analytical information and considered that a Royal Commission on the whole subject was long overdue. Government help on a modest scale was needed, and he felt an analogy with the successful University Grants Committee was sound and could be fruitful.

At the annual general meeting, Dr. W. E. Swinton, British Museum (Natural History), was elected president and Sir Philip Hendy and Prof. Lionel Robbins vice-presidents for the ensuing year.

A successful feature of the conference was the large number of working parties which had been arranged at the larger museums and art galleries in London. These were much appreciated by both the Dutch and British delegates and led to many useful discussions in which small groups benefited greatly from the expert knowledge of the staffs concerned.

Receptions were on a lavish scale and included an evening one at the National Gallery which was graced by the presence of Her Majesty Queen Elizabeth the Queen Mother, patron of the Museums Association, a spectacular reception at the Guildhall given by the Corporation of London and smaller groups at the Wellcome Historical Museum of Medical Science and the Iveagh Bequest, Kenwood. The annual dinner was held at the Goldsmiths' Hall and the conference concluded with field meetings at Brighton, Petworth House, Saltwood Castle and Canterbury, Cambridge and St. Albans. It was decided to hold the next conference in Worthing during June 15-20, 1959.

\title{
THE BACKGROUND TO SPECIALIST TECHNOLOGICAL EDUCATION
}

\author{
By DR. M. L. R. PETTERSSON \\ Brunel College of Technology, Acton, London, W.3
}

$\mathrm{H}$ OW does, how should, the content of a course for the diploma in technology differ from that of a traditional honours degree course? It is the present purpose to attempt, in part, to give an answer to this question. The tradition of technical education, often by apprenticeship, can be traced back to the earliest stages of human society. The educational tradition of scholarly book learning, on the other hand, has evolved only in the past 1 per cent of human existence. The medieval universities and schools took their character almost entirely from the scholarly tradition. Yet it is by a blending of these two kinds of activity that the flowering of modern science has arisen; to produce the change from the agricultural to the industrial stage of human society.

To what extent is present-day education adapted to the needs of our children, in contemporary industrial society? We have in Britain, comparatively, an extremely good educational system. But since society is developing with such rapidity, both recent reforms and further changes appear inevitable. Confining attention to grammar school and college education, the following five points are offered for consideration.

(1) At the Renaissance, attention to ancient writers was a progressive change. But to-day, whether in English, languages, history or the sciences, too little consideration is often given to the past ten, thirty and a hundred years.

(2) Though the medieval scholarly tradition of book learning has already been much blended with practical manual activities, most school and some college laboratories could do with ten times the costly equipment, space and technician assistance, to give fully effective courses.

(3) The medieval scholarly tradition is mainly of 'pure' studies. It is suggested that in the later years of nearly everyone's education there could well be a higher proportion of applied aspects, both those of use to the general citizen and those which are specifically vocational. This could make higher education 